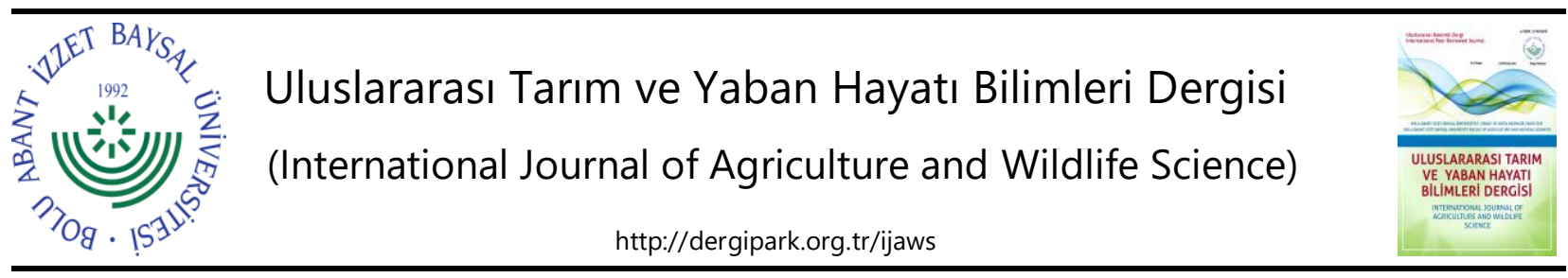

Araştırma Makalesi

\title{
Ülkemizde Yetiştirilen Bazı Fasulye (Phaseolus vulgaris L.) Çeşitlerinin BCMV ve BCMNV'e Karşı Dayanıklılık Kaynaklarının Belirlenmesi
}

\author{
Gülsüm Palacıoğlu', İzel Şanlı', Harun Bayraktar ${ }^{1 *}, \quad$ Göksel Özer ${ }^{2}$ \\ ${ }^{1}$ Ankara Üniversitesi, Ziraat Fakültesi Bitki Koruma Bölümü, Ankara \\ ${ }^{2}$ Bolu Abant İzzet Baysal Üniversitesi, Ziraat Fakültesi, Bitki Koruma Bölümü, Bolu \\ Geliş tarihi (Received): 08.06.2020 Kabul tarihi (Accepted): 11.08.2020
}

\begin{abstract}
Anahtar kelimeler:
Özet. Bean common mosaic virus (BCMV) ve Bean common mosaic necrosis virus (BCMNV) dünyada $B C M V$, BCMNV, dayanıklılık, fasulye üretim alanlarında yaygın olarak görülen ve önemli verim kayıplarına neden olan hastalık fasulye, moleküler markör etmenleridir. Bu hastalık etmenlerine karşı en etkili ve pratik mücadele yöntemi ise dayanıklı çeşit kullanılmasıdır. Bu kapsamda dünyada bu etmenlere karşı dayanıklılıkla ilişkili çok sayıda gen ve bunlarla ilişkili moleküler markör tespit edilmiş olup ıslah çalışmalarında yaygın olarak kullanılmaktadır. Bu çalışmada ise ülkemizde yaygın olarak yetiştirilen 39 adet fasulye çeşidinin BCMV ve BCMNV hastalıklarına karşı dayanıklılık kaynakları farklı moleküler markörler (SW-13, SBD-5, ROC11, elFE4) kullanılarak araştırılmıştır. Elde edilen sonuçlar test edilen fasulye genotiplerinden 11 adedinin tek bir dayanıklılık geni içerdiğini göstermiştir. Ayrıca farklı dayanıkııık gen kombinasyonları bakımından 25 fasulye çeşidinde $I+b c-1^{2}$ genlerinin bulunduğu görülmüştür. Fransız, Karabacak ve

*Sorumlu yazar

bayrakta@agri.ankara.edu.tr

40 Günlük fasulye çeşitlerinde ise dayanıklıı̆ın $b c-1^{2}$ ve $b c-3$ genleri ile kontrol edildiği tespit edilmiştir. Yapılan çalışma ile tespit edilen dayanıklıık genlerinin söz konusu hastalıklara karşı dayanıklı ıslah materyallerinin geliştirilmesinde önemli birer dayanıklıık kaynağı olarak kullanılabilecekleri düşünülmektedir.
\end{abstract}

\section{Determination of Resistance Sources to BCMV and BCMNV in Some Common Bean (Phaseolus vulgaris L.) Cultivars Grown in Turkey}

\begin{tabular}{|c|c|}
\hline Keywords: & Abstract. Bean common mosaic virus (BCMV) and Bean common mosaic necrosis virus (BCMNV) \\
\hline & are the common plant pathogens that cause significant yield losses in bean growir \\
\hline & $\begin{array}{l}\text { The most effective and practical control method is to use of resistant common bean cultivars to } \\
\mathrm{BCMV} \text { and } \mathrm{BCMNV} \text {. Many genes and molecular markers associated with resistance to these } \\
\text { pathogens have been identified and used widely in breeding studies in the world. This study } \\
\text { evaluated the presence of resistance sources in } 39 \text { common bean cultivars, widely grown in Turkey } \\
\text { to } B C M V \text { and BCMNV with different molecular markers (SW- } 13, \text { SBD-5, ROC } 11 \text {, elFE4). Eleven } \\
\text { common bean cultivars contained only one resistance gene. Also, the cultivars were evaluated for } \\
\text { resistance gene combinations to these pathogens; twenty-five cultivars possessed gene combination } \\
\text { of } I+b c-1^{2} \text {. Resistance in FransIz, Karabacak and } 40 \text { Günlük cultivars was controlled by the } b c-1^{2} \text { and } \\
b c-3 \text { gene combination. These resistance genes identified in this study could be used as valuable } \\
\text { resistance sources for developing breeding materials resistant to BCMV and BCMNV. }\end{array}$ \\
\hline
\end{tabular}




\section{GíRiş}

Leguminosae familyasında yer alan fasulye (Phaseolus vulgaris L.) bitkisi insan beslenmesi açısından önemli bir protein kaynağıdır. Ülkemizde hemen hemen her bölgede fasulye yetiştiriciliği yapılmakta olup taze fasulye üretimi en fazla Karadeniz bölgesinde, kuru fasulye üretimi ise genelde iç Anadolu bölgesinde gerçekleştirilmektedir (TUiK, 2020). Dünyada yaygın olarak tüketilmesine rağmen baklagiller içerisinde önemli bir yere sahip olan fasulye üretimi çok sayıda fungal, bakteriyel ve viral hastalık etmenlerinden dolayı istenilen düzeyde gerçekleştirilememektedir (Hall, 1994). Fasulye bitkisinde sorun olan viral hastalık etmenleri arasında ise Bean common mosaic virus (BCMV) ve Bean common mosaic necrosis virus (BCMNV) tüm dünyada en yaygın olarak bulunan ve en önemli virüs hastalıkları olarak nitelendirilmektedir (Morales ve Bos, 1988).

Potyviridae familyasında yer alan BCMV ve BCMNV fasulye üretim alanlarında enfekteli tohum, bitki özsuyu, polen ve yaprak bitleri ile taşınmakta ve fasulye bitkisinde verim ve kaliteyi düşürerek \%80'e varan ürün kayıplarına neden olduğu bildirilmektedir (Hall, 1994; Chew ve ark., 2010). Her iki hastalık etmeni de enfekteli bitkilerde açıkkoyu yeşil mozaik belirtilerine, yaprak kıvrılması, şekil bozukluğu ve kloroz gibi simptomlara neden olmaktadır. Aynı zamanda fasulye bitkilerinde dayanıklılık genine bağlı olarak sistemik nekroz, diğer adıyla tepe nekrozu (top necrosis) veya siyah kök (black root) belirtileri bu etmenler tarafından oluşturulabilmektedir. Sistemik nekroz yaprak bitlerinin yaprağı enfekte ettiği noktadan veya vasküler nekrozun ilerlemesi ile oluşmakta ve bitki ölümlerine sebep olabilmektedir (Hall, 1994).

$B C M V$ ve $B C M N V$ ile mücadelede hastalıktan ari tohum kullanılması ve yaprak bitleri ile mücadele edilmesi önerilmekle beraber dünyada en etkili ve pratik mücadele yöntemi olarak dayanıklı çeşitlerin kullanılması önerilmektedir (Drijfhout, 1978; Hall, 1994; Miklas ve ark., 2000). Bu kapsamda BCMV ve BCMNV'e karşı dayanıklıı̆ın dominant I geni ve 6 farklı resesif gen $\left(b c-u, b c-1 / b c-1^{2}, b c-2 / b c-2^{2}\right.$ ve $\left.b c-3\right)$ ile yönetildiği belirtilmektedir (Drijfhout, 1978; Kelly ve ark., 1995). Dayanıklılık gen interaksiyonuna dayanılarak bu etmenler 1'den 8'e kadar numaralandırımış 8 patogrub içerisinde sınıflandırılmıştır (Drijfhout ve Morales, 2005; Feng ve ark., 2015). Fasulye genotipleri ise farklı dayanıklılık allel kombinasyonlarına göre 1'den 11'e kadar sınıflandırılan konukçu gruplarına ayrılmıştır (Drijfhout ve Morales, 2005). BCMNV sadece PG-3 ve PG-5 ile ilişkili iken, BCMV tüm patogruplarla ilişkili olabilmektedir (Drijfhout, 1978; Feng ve ark., 2015). Dominant / geni BCMV'nin tüm streynlerine karşı tek başına dayanıklılık sağlarken, BCMNV streynleri bitkilerdeki / genini kırarak ölümcül hipersensetif reaksiyona neden olabilmektedir. Bu kapsamda etmenlere karşı dayanıklılıkta I geninin farklı dayanıklılık mekanizmalarına sahip diğer resesif genlerle $\left(b c-u, b c-1 / b c-1^{2}, b c-2 / b c-2^{2}\right.$ ve $\left.b c-3\right)$ bir araya getirilerek dayanıkılık sağlanması hedeflenmektedir (Mukeshimana ve ark., 2005). Fasulye bitkisindeki farklı gen kombinasyonlarına göre etmenlerin farklı streynlerine karşı dayanıklılık sağlanmakta olup $b c-3$ geninin BCMVBCMNV'nin tüm streynlerine karşı dayanıklılık sağladığı belirtilmektedir (Drijfhout, 1978; Miklas ve ark., 1998).

Dünyada fasulye ıslah programlarında farklı dayanıklılık gen piramitlerinin oluşturulması amacıyla yoğun çalışmalar gerçekleştirilmektedir (Pasev ve ark., 2013; Wani ve ark., 2017; Ruhımbana ve Mutlu 2019). Dayanıklılık genleri klasik yöntemler kullanılarak tespit edilebilmesine rağmen karşılaşılan zorluklar nedeniyle fasulyedeki dayanıkııık genleri ile ilişkili pek çok markör geliştirilmiş olup ıslah çalışmalarında yaygın olarak kullanılmaktadır (Melotto ve ark., 1996; Johnson ve ark., 1997; Miklas ve ark., 2000; Naderpour ve ark., 2010). Önemli bir fasulye üreticisi konumunda olan ülkemizde ise BCMV ve BCMNV'nin durumu ve dayanıklılıkta rol oynayan genler hakkında sınırlı bilgi bulunmaktadır (Deligöz ve Sökmen 2013; Deligöz ve ark., 2015; Yeken ve ark., 2018). Bu çalışma kapsamında ise ülkemizde yaygın olarak yetiştirilen fasulye çeşitlerinde BCMV ve BCMNV'e karşı dayanıklılıkta rol oynayan bazı genlerin SCAR ve CAPS markörler ile tespit edilmesi amaçlanmıştır.

\section{MATERYAL VE METOT}

\section{Bitkilerin Yetiştirilmesi}

$B C M V$ ve BCMNV'e karşı dayanıklılık genlerinin belirlenmesi amacıyla ülkemizde yaygın olarak yetiştirilen 39 fasulye çeşidi kullanılmıştır (Çizelge 1). Ayrıca PCR reaksiyonlarını doğrulamak için dayanıklılık kaynakları bilinen ve USDA'dan (United States Department of Agriculture Research Service, ABD) elde edilen 6 adet fasulye genotipi (Perry Merrow, Cornell, Michigan Dark Red Kidney (MDRK), To) kontrol amacıyla çalışmaya dâhil edilmiştir. Tohumlar ekimden önce \%1'lik sodyumhipoklorit' de $(\mathrm{NaOCl}) 2$ dakika tutulmuş ve bunu takiben 3 seri steril saf sudan geçirilerek toprak, kum, gübre karışımı içeren (1:1:1 v/v) $16 \mathrm{~cm}$ çapındaki saksılara ekilmiştir. Tüm bitkiler $23^{\circ} \mathrm{C}$ sıcaklık ve $14 / 10$ saat ışık periyodu içeren kontrollü koşullardaki bitki yetiştirme odasında 10 gün süreyle yetiştirilmiştir. 
Palacıoğlu ve ark., Ülkemizde Yetiştirilen Bazı Fasulye (Phaseolus vulgaris L.) Çeşitlerinin BCMV ve BCMNV'e Karşı Dayanıklıık Kaynaklarının Belirlenmesi

Çizelge 1. Çalışmada kullanılan fasulye çeşitlerinin özellikleri ve BCMV ve BCMNV'e karşı sahip oldukları dayanıklılık kaynakları Table 1. Characteristics of common bean cultivars and their resistance sources to BCMV and BCMNV.

\begin{tabular}{|c|c|c|c|c|c|c|}
\hline \multirow[b]{2}{*}{$\begin{array}{l}\text { Fasulye } \\
\text { Çeşitleri }\end{array}$} & \multirow[b]{2}{*}{$\begin{array}{l}\text { Fasulye } \\
\text { Tipi }\end{array}$} & \multirow{2}{*}{$\begin{array}{l}\text { Fasulye Tohumlarının Elde Edildiği } \\
\text { Yerler }\end{array}$} & \multicolumn{4}{|c|}{$\begin{array}{c}\text { BCMV-BCMNV'e Karşı Dayanıklılık } \\
\text { Kaynakları }\end{array}$} \\
\hline & & & $\begin{array}{c}\text { Igeni } \\
\text { (SW- } \\
13) \\
\end{array}$ & $\begin{array}{c}b c-1^{2} \\
(\mathrm{SBD}-5)\end{array}$ & $\begin{array}{c}b c-3 \\
\text { (ROC- } \\
11)\end{array}$ & $\begin{array}{c}b c-3 \\
\text { (elFE4 } \\
\text { ) }\end{array}$ \\
\hline Seher yıldızı & Taze & Karadeniz Tar. Arş. Enst. & - & + & - & - \\
\hline Zeynebim & Taze & Karadeniz Tar. Arş. Enst. & - & + & - & - \\
\hline Boncuk & Taze & Geçit Kuşağı Tar. Arş. Enst. & + & + & - & - \\
\hline Fransız & Taze & Geçit Kuşağı Tar. Arş. Enst. & - & + & + & + \\
\hline 40 Günlük & Taze & Geçit Kuşağı Tar. Arş. Enst. & - & + & + & + \\
\hline Karabacak & Taze & Geçit Kuşağı Tar. Arş. Enst. & - & + & + & + \\
\hline Sazova & Taze & Geçit Kuşağı Tar. Arş. Enst. & + & + & - & - \\
\hline Gina & Taze & May Tohum & + & + & - & - \\
\hline Magnum & Taze & May Tohum & + & + & - & - \\
\hline Java & Taze & May Tohum & + & + & - & - \\
\hline Asya & Taze & May Tohum & + & + & - & - \\
\hline Sofia & Taze & May Tohum & - & + & - & - \\
\hline Volare & Taze & May Tohum & + & + & - & - \\
\hline Özayşe & Taze & Batı Akdeniz Tar. Arş. Enst. & - & + & - & - \\
\hline Yalova 5 & Taze & Atatürk Bahçe Kültürleri Arş. Enst. & - & + & - & - \\
\hline Yalova 17 & Taze & Atatürk Bahçe Kültürleri Arş. Enst. & - & + & - & - \\
\hline Perolar & Taze & Makrogen Tohumculuk & - & + & - & - \\
\hline Sarıkız & Taze & Makrogen Tohumculuk & + & + & - & - \\
\hline Mina & Taze & Makrogen Tohumculuk & + & + & - & - \\
\hline Gelincik & Taze & Makrogen Tohumculuk & + & + & - & - \\
\hline Tavil & Taze & Makrogen Tohumculuk & - & + & - & - \\
\hline Nazende & Taze & Makrogen Tohumculuk & + & + & - & - \\
\hline Miray & Taze & Sim Arzuman Tarım Ürünleri & + & + & - & - \\
\hline Hanımteni & Taze & Sim Arzuman Tarım Ürünleri & - & + & - & - \\
\hline Selim & Barbunya & Sim Arzuman Tarım Ürünleri & + & + & - & - \\
\hline Sırık barbunya & Barbunya & Poltar Tarım & + & + & - & - \\
\hline Klas barbunya & Barbunya & Poltar Tarım & + & + & - & - \\
\hline Buse Oturak & Barbunya & Makrogen Tohumculuk & + & + & - & - \\
\hline Belinay Sırık & Barbunya & Makrogen Tohumculuk & - & + & - & - \\
\hline Sembol & Barbunya & Makrogen Tohumculuk & + & + & - & - \\
\hline Zülbiye & Kuru & Karadeniz Tar. Arş. Enst. & + & + & - & - \\
\hline Akın & Kuru & Geçit Kuşağı Tar. Arş. Enst. & + & + & - & - \\
\hline Önceler & Kuru & Geçit Kuşağı Tar. Arş. Enst. & + & + & - & - \\
\hline Karacaşehir90 & Kuru & Geçit Kuşağı Tar. Arş. Enst. & + & + & - & - \\
\hline Göynük 98 & Kuru & Geçit Kuşağı Tar. Arş. Enst. & + & + & - & - \\
\hline Bulduk & Kuru & Geçit Kuşağı Tar. Arş. Enst. & + & + & - & - \\
\hline Mecidiye & Kuru & Doğu Anadolu Tar. Arş. Enst. & + & + & - & - \\
\hline Aras & Kuru & Doğu Anadolu Tar. Arş. Enst. & + & + & - & - \\
\hline Yakutiye & Kuru & Doğu Anadolu Tar. Arş. Enst. & + & - & - & - \\
\hline
\end{tabular}

\section{DNA Ekstraksiyonu}

DNA ekstraksiyonu Diversity Arrays Technology (DArT) yöntemi kullanılarak gerçekleştirilmiştir (http://www.diversityarrays.com). Her fasulye çeşidinin yapraklarından yaklaşık $100 \mathrm{mg}$ bitki dokusu alınarak $1 \mathrm{ml}$ ekstraksiyon bufferı (125 mM Tris- $\mathrm{HCl}$ pH:8, $25 \mathrm{mM}$ EDTA pH:8, $0.8 \mathrm{M} \mathrm{NaCl}$ \%1 CTAB, \%1 sarcosyl, \%2 PVP-40 (K29-32), \%0.5 sodium disulphite) içerisinde homojenize edilmiş ve $65^{\circ} \mathrm{C}^{\prime}$ de 1 saat inkübasyona bırakılmıştır. Ardından her bir örneğe eşit hacim kloroform-isoamilalkol (24:1 v/v) eklenerek iyice karıştırılmış ve 10.000 g'de 20 dakika santrifüj edilmiştir. Üst sıvı temiz eppendorf tüplere alınarak eşit hacimde soğuk isopropanol eklenmiş ve 1 saat $-20^{\circ} \mathrm{C}^{\prime}$ de bekletilmiştir. DNA'yı çöktürmek için örnekler $10.000 \mathrm{~g}$ 'de 5 dakika santrifüj edildikten sonra üst sıvı dökülmüş ve DNA pelleti $500 \mu \mathrm{l} \% 70^{\prime}$ lik soğuk ethanol ile yıkanmıştır. Oda koşullarında kurutulduktan sonra pellet $100 \mu \mathrm{l}$ steril $\mathrm{ddH}_{2} \mathrm{O}$ ile çözülmüştür. DNA konsantrasyonları spektrofotometrik olarak (NanoDrop-1000 
Palacıoğlu ve ark., Ülkemizde Yetiştirilen Bazı Fasulye (Phaseolus vulgaris L.) Çeşitlerinin BCMV ve BCMNV'e Karşı Dayanıklılık Kaynaklarının Belirlenmesi

spectrophotometer, Thermo Scientific) 260/280 nm'de ölçüm yapılarak belirlenmiş ve tüm DNA örnekleri $20 \mathrm{ng}$ $\mu \mathrm{I}^{-1}$ olacak şekilde seyreltilerek $-20^{\circ} \mathrm{C}^{\prime}$ de saklanmıştır.

\section{Fasulye Çeşitlerindeki Dayanıklılık Kaynaklarının Moleküler Markörler ile Tespiti}

Fasulye bitkisinde BCMV ve BCMNV'e karşı dayanıklılık genleri ile ilişkili olduğu bildirilen 3 SCAR markör ve 1 adet CAPS markör çalışma kapsamında kullanılmışır (Çizelge 2). PCR reaksiyonları $0.2 \mu \mathrm{M}$ dNTPs, $0.3 \mu \mathrm{M}$ primer, $1.5 \mathrm{mM} \mathrm{MgCl}$, 10x PCR buffer, 20-30 ng DNA, 1U Taq DNA polimeraz içeren $25 \mu$ l'lik hacimlerde gerçekleştirilmiştir. PCR amplifikasyonları ise her primer için Çizelge 2'de belirtilen koşullar kullanılarak gerçekleştirilmiştir. Elde edilen PCR ürünleri \%1.2'lik agaroz jelde, 1XTAE buffer içerisinde 100 V'da elektroforetik olarak ayrılarak gözlenmiş ve beklenilen PCR ürünlerinin büyüklükleri Gene Ruler 100 bp DNA ladder (Thermo Scientific) kullanılarak tespit edilmiştir. Dayanıklılık genleri ile ilişkili amplifikasyon ürünlerinin varlığı, referans çeşitler ile kıyaslanarak var (+), yok (-) olarak belirlenmiştir. Ayrıca bc-3 dayanıklılık genini belirlemek için elFE4 markörü ile elde edilen PCR ürünlerinin $10 \mu l$ 'si, üretici firma protokolüne göre Rsal (Thermo Scientific) enzimi ile kesilmiş ve \% 1.2'lik agaroz jelde 100 V'da elektroforetik olarak ayrılarak kaydedilmiştir.

Çizelge 2. Çalışmada kullanılan dayanıklılık genleri ile ilişkili primerlerin özellikleri ve PCR koşulları. Tablo 2. Characteristics of the primers linked to resistance genes and PCR conditions used in the study.

\begin{tabular}{|c|c|c|c|c|c|}
\hline Primer & $\begin{array}{l}\text { Gen } \\
\text { Lokusu }\end{array}$ & Baz çifti & $\begin{array}{l}\text { PCR } \\
\text { Ürünü } \\
\text { (bp) }\end{array}$ & PCR koşulları & Kaynak \\
\hline SW-13 & I & $\begin{array}{l}\text { 5'-CACAGCGACATTAATTTTCCTTTC-3' } \\
5^{\prime} \text {-CACAGCGACAGGAGGAGCTTATTA - } \\
3^{\prime}\end{array}$ & 690 & $\begin{array}{l}95^{\circ} \mathrm{C} 4 \mathrm{dk} \\
94^{\circ} \mathrm{C} 10 \mathrm{~s}, 60^{\circ} \mathrm{C} 40 \mathrm{~s} \\
72^{\circ} \mathrm{C} 2 \mathrm{dk} 35 \text { döngü } \\
72^{\circ} \mathrm{C} 5 \mathrm{dk}\end{array}$ & $\begin{array}{l}\text { Melotto ve ark. } \\
\text { (1996) }\end{array}$ \\
\hline SBD-5 & $b c-1^{2}$ & $\begin{array}{l}\text { 5'-GTGCGGAGAGGCCATCCATTGGTG- } \\
\text { 3' } \\
\text { 5'-GTGCGGAGAGTTTCAGTGTTGACA-3' }\end{array}$ & 1250 & $\begin{array}{l}95^{\circ} \mathrm{C} 4 \mathrm{dk} \\
94^{\circ} \mathrm{C} 10 \mathrm{~s}, 65^{\circ} \mathrm{C} 40 \mathrm{~s}, \\
72^{\circ} \mathrm{C} 2 \mathrm{dk}, 35 \text { döngü } \\
72^{\circ} \mathrm{C} 5 \mathrm{dk}\end{array}$ & $\begin{array}{l}\text { Miklas ve ark. } \\
(2000)\end{array}$ \\
\hline ROC11 & $b c-3$ & $\begin{array}{l}\text { 5'-CCAATTCTCTTCACTTGTAACC-3' } \\
\text { 5'-GCATGTTCCAGCAAACC -3' }\end{array}$ & $420 / 350$ & $\begin{array}{l}95^{\circ} \mathrm{C} 4 \mathrm{dk} \\
94^{\circ} \mathrm{C} 10 \mathrm{~s}, 65^{\circ} \mathrm{C} 10 \mathrm{~s}, \\
72^{\circ} \mathrm{C} 30 \mathrm{~s} 35 \text { döngü } \\
72^{\circ} \mathrm{C} 5 \mathrm{dk}\end{array}$ & $\begin{array}{l}\text { Johnson ve ark. } \\
\text { (1997) }\end{array}$ \\
\hline elFE4 & $b c-3$ & $\begin{array}{l}\text { 5'-ACCGATGAGCAAAACCCTA-3' } \\
\text { 5'-CAACCAACTGGTATCGGATT-3' }\end{array}$ & $\begin{array}{l}541 / \text { Rsal } \\
(381+16 \\
0)\end{array}$ & $\begin{array}{l}95^{\circ} \mathrm{C} 3 \mathrm{dk} \\
94^{\circ} \mathrm{C} 20 \mathrm{~s}, 58^{\circ} \mathrm{C} 20 \mathrm{~s}, \\
72^{\circ} \mathrm{C} 20 \mathrm{~s}, 40 \text { döngü } \\
72^{\circ} \mathrm{C} 5 \mathrm{dk}\end{array}$ & $\begin{array}{l}\text { Naderpour ve } \\
\text { ark. (2010) }\end{array}$ \\
\hline
\end{tabular}

\section{BULGULAR VE TARTIŞMA}

$B C M V$ ve $B C M N V$ ülkemizde ve dünyada fasulye üretim alanlarında yaygın olarak görülen ve mozaik belirtisi, yaprak kıvrılması ve sistemik nekroza neden olarak önemli ekonomik kayıplar oluşturan hastalık etmenleridir. Bu etmenlere karşı konukçu bitki dayanıklılığın kullanımı ise en etkili mücadele yöntemi olarak belirtilmektedir (Drijfhout, 1978; Hall, 1994; Miklas ve ark., 2000). Bu kapsamda BCMV ve BCMNV'e karşı bazı dayanıklılık genleri belirlenmiş olup bu dayanıklılık kaynakları ile ilişkili moleküler markörler ıslah çalışmalarında yaygın olarak kullanılmaktadır (Haley ve ark. 1994; Melotto ve ark., 1996; Johnson ve ark., 1997; Strausbaugh ve ark., 1999; Miklas ve ark., 2000; Naderpour ve ark., 2010). Ülkemizde ise fasulye üretim alanlarında söz konusu etmenlerin tespiti ve yaygınlığı ile ilgili çalışmalar gerçekleştirilmesine rağmen dayanıklıık kaynakları hakkında oldukça az çalışma bulunmaktadır (Deligöz ve Sökmen, 2013, Deligöz ve ark., 2015). Bu çalışma kapsamında ülkemizde yaygın olarak yetiştirilen 39 fasulye çeşidindeki BCMV ve BCMNV'e karşı dayanıklııık kaynaklarının $\left(b c-1^{2}, 1, b c-3\right)$ farklı SCAR ve CAPS markörler ile tespit edilmesi amaçlanmıştır. Yapılan optimizasyon çalışmaları sonucunda tüm primerlerin bitki örneklerinden beklenen büyüklükte PCR ürünlerinin amplifikasyonunu sağladığı görülmüştür (Şekil 1).

Fasulye bitkisinde BCMV ve BCMNV'e karşı hipersensitif reaksiyona neden olan dominat / geninin belirlenmesi için kullanılan SCAR markör SW-13 test edilen örneklerden 690 bp büyüklüğünde bir amplifikasyon ürününün çoğalmasını sağlamışırı (Şekil 1). Elde edilen sonuçlar referans fasulye genotipi TO'nun yanı sıra ülkemizde yetiştirilen 26 fasulye çeşidinde bu dayanıkılık geninin bulunduğunu göstermiştir (Çizelge 1). Bu çalışmada elde edilen sonuçlar ile uyumlu olarak SW13 markörü Andean ve Mesoamerikan gen havuzuna ait fasulye genotiplerindeki / geninin varlığını belirlemek için ıslah çalışmalarında geniş bir kullanım alanı bulmuştur (Melotto 
ve ark., 1996; Pasev ve ark., 2013). Fasulye bitkisinde $b c-1^{2}$ dayanıklılık geni ile ilişkili olan SCAR markör SBD-5 ise test edilen örneklerden 1250 bp büyüklüğünde spesifik bir PCR ürününün çoğalmasını sağlamıştır (Şekil 1). Bu kapsamda ülkemizde yetiştirilen fasulye çeşitlerinden Yakutiye hariç tüm fasulye çeşitlerinin bu dayanıklıık genini taşıdıkları gözlemlenmiştir (Çizelge 1). Ayrıca kontrol olarak Perry Marrow fasulye genotipinde 1250 bp'lik bir ürün elde edilirken Cornell genotipinde herhangi bir amplifikasyon gözlemlenmemiştir. SW-13 ve SBD-5 markörleri ile multipleks-PCR yöntemini kullanarak 5 fasulye çeşidi ve bir ıslah hattında dominant I geni ve resesif $b c-1^{2}$ genini araştıran Deligöz ve Sökmen (2013) ise tüm örneklerin $b c-1^{2}$ genine sahip olduğunu ayrıca bu çalışmada da kullanılan Zülbiye çeşidi ile diğer iki çeşitte dominant / geninin bulunduğunu belirtmişlerdir. Ayrıca araştırıılar ülkemizde tescilli ticari ve yerel fasulye çeşitlerinde BCMV ve BCMNV"ye karşı dayanıklılı̆ı sağlayan genlerin belirlenmesinin gerekli olduğunu ifade etmişlerdir. BCMV-NL-4 ırkı ile yerel fasulye çeşitlerinin inoküle edildiği bir diğer çalışmada ise Deligöz ve ark. (2015) ülkemizde yetiştirilen 31 ticari çeşidin 24 adedini BCMV'ye karşı dayanıklı 7 tanesini ise hassas olarak belirlemiştir. Benzer şekilde ülkemizdeki bazı fasulye çeşitlerinde dominant $/$ ve $b c-1^{2}$ genini araştıran Yeken ve ark. (2018) test edilen fasulye çeşitlerinde bu genlerin yaygın olarak bulunduğunu belirtmişlerdir.
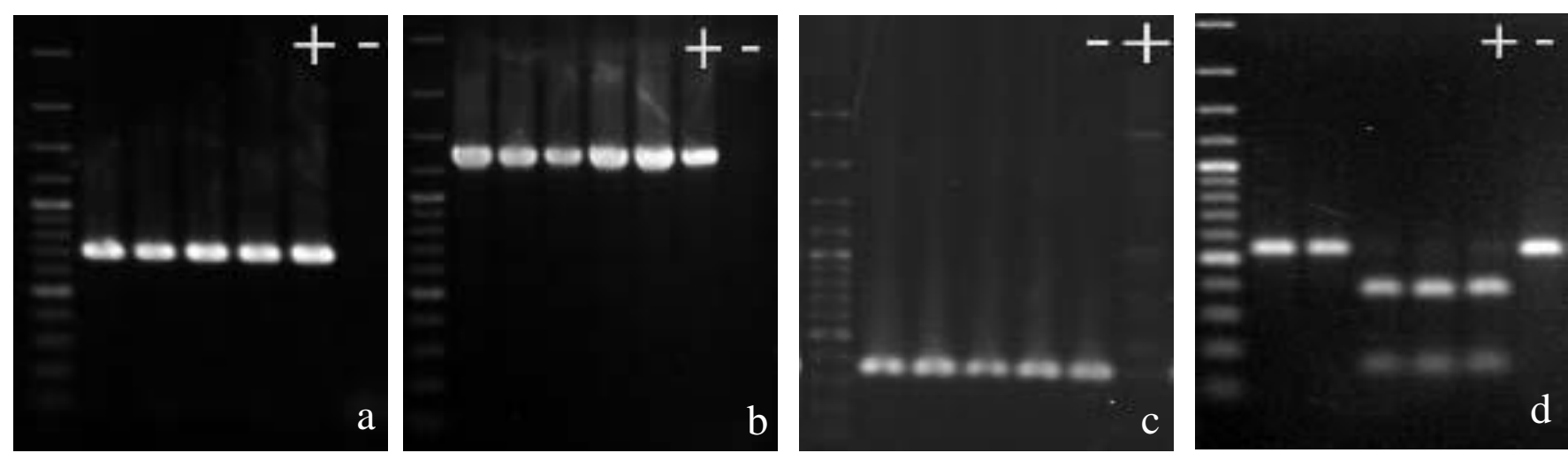

Şekil 1. Fasulye bitkisinde $B C M V$ ve $B C M N V$ 'e karşı dayanıklılıkta rol oynayan genlerin spesifik primerlerle amplifikasyonu sonucu elde edilen bant profilleri.(a: dominat I geninin SW-13 markörü ile amplifikasyonu sonucu elde edilen spesifik PCR ürünü, To (+), MDRK (-), b: bc- $7^{2}$ geninin SBD-5 markörü ile amplifikasyonu sonucu elde edilen spesifik PCR ürünü, Perry Marrow $(+)$, Cornell (-), c: bc-3 geninin Roc-11 markörü ile amplifikasyonu sonucu elde edilen spesifik PCR ürünü, Perry Marrow (-), Cornell (+), d: elFE4 primeri ile amplifiye edilen ve Rsal ile kesilen bc-3 geninin enzim profili, Fransız (+), Sazova (-). Markör: GeneRuler 100 bp DNA ladders, Thermo Scientific).

Figure 1. Band profiles showing amplification of genes associated with resistance to BCMV and BCMNV in common bean (a: PCR product of dominate I gene amplified with specific-primer SW-13, To (+), MDRK (-), b: PCR product of bc- $1^{2}$ gene amplified with specific-primer SBD-5, Perry Marrow (+), Cornell (-), c: PCR product of bc-3 gene amplified with specific-primer Roc-11, Perry Marrow (-), Cornell (+), d: restriction profiles of bc-3 gene amplified with elFE4 primer and digested with Rsal enzyme, Fransiz (+), Sazova (-). Marker: GeneRuler 100 bp DNA ladders, Thermo Scientific)

Fasulye bitkilerindeki $b c-3$ geninin tespiti için ROC-11 ve elFE4 markörleri kullanılmıştır. ROC-11 markörü ile 420 bp büyüklüğünde bir bandın elde edilmemesi bu çeşitlerde $b c-3$ geninin bulunmadığı şeklinde değerlendirilmiştir (Şekil 1). Bu kapsamda test edilen fasulye çeşitlerinden sadece Fransız, Karabacak ve 40 Günlük çeşitlerinde $b c-3$ geninin bulunduğu belirlenmiştir (Çizelge 1). Ancak diğer çeşitlerde 350 bp büyüklüğünde bir PCR ürünü elde edilmiş olup benzer sonuçlar farklı araştırıcılar tarafından da gözlemlenmiştir. Blair ve ark. (2004) ROC-11 primerinin Andean gen havuzuna ait hassas genotiplerin çoğunda bu amplifikasyon ürününü çoğalttığını ancak dayanıklı Andean genotiplerinde bu PCR ürününün bulunmadığını belirtmiştir. Pasev ve ark. (2013) bc-3 genine sahip genotiplerde bu bandın bulunmadığını diğer tüm genotiplerde ise 350 bp büyüklügündeki amplifikasyon ürününün oluştuğunu belirtmişlerdir. Ayrıca bu durum bağlanma bölgelerindeki insertion/deletionlar veya ROC11/350 ve ROC11/420 sekansları arasındaki benzerlikten kaynaklanmasının da olası olduğu düşünülmektedir (Johnson ve ark., 1997; Pasev ve ark., 2013). Yapılan çalışmada fasulye çeşitlerinden elFE4 markörü ile elde edilen $P C R$ ürününün $R s a l$ enzim kesimi ile bu örneklerde $b c-3$ geninin varlığı ayrıca doğrulanmıştır (Çizelge 1). Enzim kesimi sonucunda $b c-3$ geninin bulunmadığı çeşitlerde 541 bp büyüklüğünde tek bir ürün elde edilir iken $b c-3$ geninin bulunduğu çeşitlerde 381 ve 160 bp büyüklüğünde iki PCR-RFLP ürünü elde edilmiştir (Şekil 1). Bu kapsamda sadece Fransız, Karabacak ve 40 Günlük çeşitlerinde $b c-3$ geninin bulunduğu elFE4 markörü ile de doğrulanmıştır. Ayrıca test edilen fasulye çeşitlerinden Bulduk fasulye çeşidi 350 bp'lik bir ürün vermemiş ancak her iki markörle de negatif sonuç vermiştir. Johnson ve ark. (1997) ROC-11 markörü ile bc-3 geninin tespitinin Andean kökenli fasulye genotiplerinde yararlı iken, Mesoamerikan kökenli bazı fasulye genotiplerinde farklı sonuçlar verebileceğini belirtmişlerdir. Benzer şekilde $b c-3$ geni ile ilişkili markörleri kullanan 
Naderpour ve ark. (2010) bu markörlerin bc-3 geni bulunan USCR8 ve bulunmayan DW fasulye genotiplerini ayırmadığını belirtmiştir.

Farklı dayanıklıık genlerini kombine olarak içeren fasulye çeşitleri BCMV ve BCMNV'nin tüm streynlerine ve patogruplarına karşı daha stabil ve geniş spektrumlu bir dayanıklılık sağlanması nedeniyle ıslah programlarında öncelikli olarak değerlendirilmektedir (Drijfhout, 1978; Kelly ve ark., 1995; Miklas ve ark., 2000). Islah çalışmalarında farklı gen kombinasyonlarının oluşturulması fasulye çeşitlerine uzun süreli dayanıklılık kazandırılması açısından oldukça önemli olup en etkili dayanıklılı̆ın $I+b c-u+b c-2^{2}+b c-3$ gen kombinasyonu olduğu belirtilmiştir (Drijfhout, 1978). Ancak bu genlerin hepsinin tek bir fasulye genotipinde bir araya gelmesinin zor olması nedeniyle günümüzde $B C M V$ ve $B C M N V$ 'nin tüm streynlerine karşı en geniş spektrumlu ve uzun süreli dayanıklıığın $I+b c-3$ ve $1+b c-2^{2}$ gen kombinasyonları ile sağlandığı bildirilmektedir (Kelly 1997; Miklas ve ark., 1998; Mukeshimana ve ark., 2005). Ülkemizde yaygın olarak kullanılan fasulye çeşitlerindeki $I, b c-1^{2}$ ve $b c-3$ dayanıklılık genlerini araştırdığımız bu çalışmada da farklı gen kombinasyonlarının bulunduğu belirlenmiştir. Yakutiye çeşidi sadece $I$ dayanıklılık genini içerir iken 10 fasulye çeşidinin sadece $b c-1^{2}$ genini içerdiği görülmüştür. Fasulye bitkilerinde tek başına $b c-1^{2}$ geninin bulunması ise BCMV'nin NL1, NL7, US2, NL2 ve BCMNV'nin NL8 streynlerine karsı dayanıklılık sağlamaktadır (Drijfhout, 1978). Gen kombinasyonları bakımından ise test edilen çeşitlerin 25 tanesinde $I+b c-1^{2}$ ve 3 adedinde $b c-1^{2}+b c-3$ genlerinin bulunduğu görülmüştür. Her üç dayanıklılık genini de içeren bir fasulye çeşidinin ise bulunmadığı gözlemlenmiştir. Fasulye bitkilerindeki $I+b c-1^{2}$ gen kombinasyonunun BCMV ve BCMNV'nin NL3 , NL-5 ve NL-6 hariç tüm streynlerine karşı dayanıkıılığı sağladığı düşünülmektedir. Miklas ve ark. (2000) ise / geni ile $b c-1^{2}$ bir arada bulunmasının tepe nekrozuna karşı dayanıklılık sağladığını belirtmiştir. Test edilen çeşitler arasında $b c-3$ genini taşıyan çeşitlerin ise her iki virüsün bütün streynlerine karşı resesif dayanıklılığa sahip olduğu görülmektedir. Ancak her iki virüse karşı bağışıklık sağladığı belirtilen $I+b c-3$ dayanıkıığı ülkemizdeki fasulye çeşitlerinde tespit edilememiştir. Bununla birlikte $b c-3$ geni fasulye bitkisinde BCMV'e karşı koruma sağlamak amacıyla ıslah çalışmalarında yaygın olarak tercih edilen bir gen olmuştur (Drijfhout, 1978; Kelly ve ark., 1995; Hart ve Griffiths, 2013). Feng ve ark., (2015) BCMV'nin fasulyedeki farklı dayanıkılık genlerini yenebilecek mekanizmalar geliştirdiğini ve yeni bir virüs streyninin $b c-2$ ve $b c-3$ dayanıklılık genlerini yenebildiğini bildirmiş̧ir. Dominant / ve resesif $b c-3$ genlerini marker destekli geri melezleme ıslahı yoluyla hassas Ruanda fasulyelerine transfer etmeyi amaçlayan Ruhımbana ve Mutlu (2019) CAPS markörlerinin elde edilen fasulye progenlerinin seçilimde başarılya kullanılabileceğini belirtmişlerdir. Benzer şekilde farklı araştııılar farklı gen kombinasyonlarını içeren fasulye genotiplerinin belirlenmesi amacıyla dayanıklıık markörlerini etkin şekilde kullanmışlardır (Mukeshimana ve ark., 2005; Bello ve ark., 2014; Boersma ve ark., 2014).

\section{SONUÇ}

Çalışma kapsamında ülkemizde yaygın olarak yetiştirilen bazı fasulye çeşitlerindeki BCMV ve BCMNV'e karşı dayanıklıık kaynakları moleküler markörler kullanılarak detaylı şekilde ortaya konulmuştur. Elde edilen sonuçlar $1+b c-1^{2}$ ve $1+b c-3$ gen kombinasyonlarının yaygın olarak bu çeşitlerdeki dayanıklılıkta rol oynağını göstermiştir. Yapılacak ıslah çalışmalarında dominat I ve resesif $b c-3$ genlerini taşıyan çeşitlere öncelik verilmesi gerektiği düşünülmektedir. BCMV ve BCMNV'nin tüm streynlerine karşı dayanıklılık sağladığı belirtilen $1+b c-3$ gen kombinasyonu ise test edilen çeşitler arasında bulunamamıştır. Bu kapsamda ülkemizdeki yerel çeşit ve genotiplerdeki farklı dayanıklılık kaynaklarının araştıııması ve değişik gen kombinasyonlarını taşıyan fasulye çeşitlerinin geliştirilmesi bu etmene karşı mücadelede daha başarılı sonuçlar sağlayacaktır. Ayrıca markör destekli seleksiyon yöntemi üzerine yapılacak ilave çalışmaların fasulye bitkisindeki diğer etmenlere karşı da ıslah çalışmalarının etkinliğinin artmasında önemli katkı sağlayacağı düşünülmektedir.

\section{ÇIKAR ÇATIŞMASI BEYANI}

Yazarlar arasında herhangi bir çıkar çatışması bulunmamaktadır.

\section{YAZAR KATKI BEYANI}

Yazarlar olarak makalenin planlanması, yürütülmesi ve yazımı tarafımızca eşit olarak yapılmıştır. 


\section{KAYNAKLAR}

Bello, M. H., Moghaddam, S. M., Massoudi, M., McClean, P. E., Cregan, P. B., \& Miklas, P. N. (2014). Application of in silico bulked segregant analysis for rapid development of markers linked to Bean common mosaic virus resistance in common bean. $B M C$ Genomics, 15(1), 903.

Blair, M. W., Buendia, H. F., Castano, M., Santana, G. E., \& Morales, F. (2004). Adaptation and use of SCAR markers for BCNMV resistance (bc-3 and dominant/genes) in an Adean bean breeding program. South African Plant Breeding Conference, Durban, South Africa.

Boersma, J. G., Conner, R. L., Balasubramanian, P. M., Navabi, A., Yu, K., \& Hou, A. (2014). Combining resistance to common bacterial blight, anthracnose, and bean common mosaic virus into Manitoba-adapted dry bean (Phaseolus vulgaris L.) cultivars. Canadian Journal of Plant Science, 94(2), 405-415.

Chew, M. Y. I., Velásquez, V. R., Mena, C. J., \& Gaytán, M. A. (2010). Virus de frijol en la Comarca Lagunera y Zacatecas. Folleto Técnico Campo Experimental Zacatecas CIRNOC-INIFAP, Zacatecaz, 41.

Deligöz, İ., \& Sökmen, M. A. (2013). Bazı fasulye genotiplerinin Bean common mosaic virus (BCMV) ve Bean common mosaic necrosis virus (BCMNV)'a dayanıklııı durumlarının kalitatif, kantitatif ve moleküler yöntemlerle belirlenmesi. Bitki Koruma Bülteni, 53(2), 101-113.

Deligöz, İ., Sarı, S., \& Karaağaç, O. (2015). Karadeniz Tarımsal Araştırma Enstitüsü tarafından geliştirilen taze fasulye ıslah hatları ve bazı ticari çeşitlerin Bean common mosaic virus (BCMV)'a dayanıklılık durumlarının araştırılması. Derim, 32(1), 1-10.

Drijfhout, E. (1978). Genetic Interaction Between Phaseolus vulgaris and Bean Common Mosaic Virus with Implications for Strain Identification and Breeding for Resistance. Centre for Agricultural Publication and Documents, Wageningen, the Netherlands.

Drijfhout, E., \& Morales, F. (2005). Bean common mosaic. In: H. F. Schwartz, J. R. Steadman, R. Hall, \& R. L. Forster (Eds.), Compendium of Bean Diseases, 2nd ed. (Pp: 60-62). APS press, St. Paul, MN.

Feng, X., Myers, J. R., \& Karasev, A. V. (2015). Bean common mosaic virus isolate exhibits a novel pathogenicity profile in common bean, overcoming the bc-3 resistance allele coding for the mutated EIF4E translation initiation factor. Phytopathology 105, 1487-1495.

Haley, S. D., Afanador, L., \& Kelly, J. D. (1994). Identification and application of a random amplified polymorphic DNA marker for the I gene (potyvirus resistance) in common bean. Phytopathology, 84(2), 157-160.

Hall, R. (1994). Bean Diseases, Bean Pathogens, Bean Disease Control. Compendium of Bean Diseases, APS press, Minnesota, USA.

Hart, J. P., \& Griffiths, P. D. (2013). A series of elF4E alleles at the Bc-3 locus are associated with recessive resistance to Clover yellow vein virus in common bean. Theoretical and Applied Genetics, 126(11), 2849-2863.

Johnson, W. C., Guzmán, P., Mandala, D., Mkandawire, A. B. C., Temple, S., Gilbertson, R. L., \& Gepts, P. (1997). Molecular tagging of the BC-3 gene for introgression into Andean common bean. Crop Science, 37(1), 248-254.

Kelly, J. D., Afanador, L., \& Haley, S. D. (1995). Pyramiding genes for resistance to bean common mosaic virus. Euphytica, 82(3), 207-212.

Kelly, J. D. (1997). A review of varietal response to bean common mosaic potyvirus in Phaseolus vulgaris. Plant Varieties and Seeds, 10(1), 1-6.

Melotto, M., Afanador, L., \& Kelly, J. D. (1996). Development of a SCAR marker linked to the I gene in common bean. Genome, 39(6), 1216-1219.

Miklas, P., Larsen, R., \& Kelly, J. (1998). Localized Vein Necrosis to BCMNV in Pinto P94207 is Conditioned by a Dominant Gene. Bean Improvement Cooperative, USA.

Miklas, P. N., Larsen, R. C., Riley, R., \& Kelly, J. D. (2000). Potential marker-assisted selection for bc-1 2 resistance to bean common mosaic potyvirus in common bean. Euphytica, 116(3), 211-219.

Morales, F. J., \& Bos, L. (1988). Bean common mosaic virus. Online publication. Descriptions of Plant Virüses No. 337. http://www.dpvweb.net7dpv/showdpv.php?dpvno=337. Access date: April 15, 2020.

Mukeshimana, G., Paneda, A., Rodríguez-Suárez, C., Ferreira, J. J., Giraldez, R., \& Kelly, J. D. (2005). Markers linked to the bc-3 gene conditioning resistance to bean common mosaic potyviruses in common bean. Euphytica, 144(3), $291-299$.

Naderpour, M., Lund, O. S., Larsen, R., \& Johansen, E. (2010). Potyviral resistance derived from cultivars of Phaseolus vulgaris carrying BC-3 is associated with the homozygotic presence of a mutated elF4E allele. Molecular Plant Pathology, 11(2), 255263. 
Palacıoğlu ve ark., Ülkemizde Yetiştirilen Bazı Fasulye (Phaseolus vulgaris L.) Çeşitlerinin BCMV ve BCMNV'e Karşı Dayanıklılık Kaynaklarının Belirlenmesi

Pasev, G., Kostova, D., \& Sofkova, S. (2013). Identification of genes for resistance to Bean common mosaic virus and Bean common mosaic necrosis virus in snap bean (Phaseolus vulgaris L.) breeding lines using conventional and molecular methods. Journal of Phytopathology, 162(1), 19-25.

Ruhımbana, C., \& Mutlu, N. (2019). Marker-assisted pyramiding potyvirus resistance genes into Rwandan common bean (Phaseolus vulgaris L.) genotypes. Mediterranean Agricultural Sciences, 32(3), 1-1.

Strausbaugh, C. A., Myers, J. R., Forster, R. L., \& McClean, P. E. (1999). bc-1 and bc-u-two loci controlling bean common mosaic virus resistance in common bean are linked. Journal of the American Society for Horticultural Science, 124(6), 644-648.

TUIK. (2020). Türkiye İstatistik Kurumu, Bitkisel Üretim İstatistikleri. http://www.tuik.gov.tr. Erişim tarihi 20 Mayıs 2020.

Yeken, M. Z., Özer, G., Çelik, A., \& Çiftçi, V. (2018). Türkiye'de ticari fasulye (Phaseolus vulgaris L.) çeşitlerinde bean common mosaic virus ve bean common mosaic necrosis virus etmenlerine dayanıklılıkla ilişkili genlerin karakterizasyonu. Türk Tarım ve Doğa Bilimleri Dergisi, 5(4), 613-619.

Wani, A. B., Bhat, M. A., Husaini, A. M., \& Sidiqi, I. (2017). Screening of important bean genotypes/collections for resistance against Common Bean Mosaic Virus using molecular markers. Journal of Pharmacognosy and Phytochemistry, 6(4), 343347. 